\title{
Genetic Diversity, Heritability and Correlation Studies for Yield and its Components in Bread Wheat under Heat Stress Conditions
}

\author{
Anzer Ul Islam ${ }^{1}$, A. K. Chhabra ${ }^{1}$, S. S. Dhanda ${ }^{1}$ and Ovais H. Peerzada ${ }^{2}$ \\ ${ }^{1}$ Department of Genetics and Plant Breeding, CCS HAU, Hisar 125004, India \\ ${ }^{2}$ Department of Seed Science and Technology, CCS HAU, Hisar 125004, India
}

\begin{abstract}
One hundred diverse bread wheat genotypes were studied for various morpho-physiological traits under timely sown and late sown conditions. The experiment were conducted during the cropping seasons 201213 and 2013-14 at research area of Wheat and Barley Section, Department of Genetics and Plant Breeding, CCSHAU, Hisar. Yield and yield contributing traits were found significant under both conditions. The estimates of GCV, PCV, heritability and genetic advance were high to moderate in timely sown and late sown conditions for the traits yield per plant, number of productive tillers, 1000 grain weight, spike length, number of spikelet per spike, flag leaf area, biological yield, cell membrane stability and grain filling rate. Correlation coefficients revealed that number of productive tillers, 1000 grain weight, number of grains per spike, biological yield, flag leaf area, cell membrane stability, grain filling duration and grain filling rate gave the positive associations with grain yield in both environments. Consequently, selection can be based on these traits in both environments for breeding of bread wheat under heat stress condition.
\end{abstract}

Keywords: Bread wheat, Correlations, Genetic diversity, Heat stress, Morpho-physiological traits

\section{Introduction}

Around the globe, global warming is predicted to increase the frequency and severity of heat stress leading to drastic reduction in the food production (Talukder et al., 2014). As a major cereal crop, wheat accounts for about $30 \%$ of the world's cereal area to provide food for $36 \%$ of the global population (Cossani \& Reynolds, 2012; Prerna et al., 2013). It has been estimated that global mean temperature is rising at $0.3 \%$ per decade which may cause 50\% decline in wheat yields in South Asia by 2050 (IFPRI, 2009). Since 1980s, global wheat productivity is estimated to have been reduced by as much as $5 \%$ due to increasing temperature (Lobell et al., 2011). It has been shown to lose $3-4 \%$ of yield per ${ }^{\circ} \mathrm{C}$ above the optimum daytime temperature of $15-20^{\circ} \mathrm{C}$ (Wardlaw et al., 1989). Wheat is traditionally grown as a cool season crop, but continuous high-temperature exerts an opposite force to reduce the plant morpho-physiological activity. Due to influence of temperature stress at anthesis and grain filling period the per plant average grain yield reduce. Several studies have confirmed that rise in temperature above a daily average temperature of $15^{\circ} \mathrm{C}$ during grain filling period reduced grain yield (Soyema et al., 2016 and Hussian et al., 2014). Now days continue fluctuation in climatic condition results in temperature climb up. In NWPZ environments of India, terminal heat stress during anthesis and grain filling period is an important constraint to limiting grain yield in winter sown spring wheat cultivars. In these areas wheat, rice cropping system laid late wheat planting and exposed crop to high temperature at the reproductive stage resulting in reduction of average grain yield in cooler regions, because the temperatures often exceeds $30^{\circ} \mathrm{C}$ during grain filling period. Terminal or late heat stress during the last phases of wheat development especially from booting, heading, anthesis and grain filling stages of the spring wheat cultivars is considered as one of the major environmental constraints that drastically reduces grain number per spike and grain weight and consequently significant reduction in wheat grain yield throughout most of the bread wheat growing areas in this region and other warm and dry regions of India. Conjoint research results from worldwide consistent, multimodal climate change assessment for major crops with explicit characterization of uncertainty (Frieler et al., 2015; Rosenzweig et al., 2014) show that climate change will fundamentally alter global food production patterns. Overall climate change will also increase variability in crop yields in many regions.

Several authors have reported shorter life cycle, reduced tillering, less biomass production, reduced fertilization and grain development, reduced head size, reduction in number of spikes per $\mathrm{m}^{2}$, number of grains per spike and grain weight as the consequences of heat stress, and all these changes are lead in reduction of grain yield under heat stress conditions (Gibson and Paulson, 1999, Ayeneh et al., 2002 and Irfaq et al., 2005). Choosing a suitable planting date and cultivar with the appropriate phenology that matches crop growth to the climate conditions will lead to optimum grain yields (Chen et al., 2003). Generally, cultivars are tested across space and time under field conditions by manipulation of date of sowing or choosing sites, which are featured by high temperature at grain filling period (Rane and Nagarajan, 2004). Increased heat tolerance in late planted wheat is very essential to enhance and stabilize wheat productivity in the tropical and subtropical countries (Irfaq-Khan et al., 2007). The magnitude of 
variability in the cultivars varies in different zones and poses practical limitations in evaluating their effective adaptation (Ali et al., 2008; Baril, 1992). To develop an effective way to find out the problem in searching the possibility for those genotypic characters which are not easily influenced by the environmental factors. Such characters, if made available to the wheat breeders will help to develop cultivars with stable performance over a wide range of heat prone areas. The suitable cultivars will then be used in wheat breeding programs for development of germplasm adapted to terminal heat stress conditions in the target environment. Grain yield is a complex trait and highly influenced by many genetic factors and environmental fluctuations. In plant breeding programme, direct selection for yield as such could be misleading. A successful selection depends upon the information on the genetic variability and association of morpho-agronomic traits with grain yield. The main goal of this study was to identify genetic sources tolerant to heat stresses that have better performance in environments with heat stress intensities.

\section{Materials And Method}

The diverse bread wheat germplasm consisted of 100 genotypes collected from different National Yield Trials at different locations including exotic lines from CIMMYT. The details of origin/source of selected genotypes are given in Table 1.

Table 1: List of wheat genotypes used in the study

\begin{tabular}{|c|c|c|c|c|c|}
\hline Sr. No. & Genotype & Developed at/Source & S. No. & Genotype & Developed at/source \\
\hline 1 & HUW 544 & BHU, Varanasi & 51 & PBW528 & PAU, Ludhiana \\
\hline 2 & $2016 \mathrm{~L}$ & IIWBR, Karnal & 52 & UP2473 & GBPUA\&T, Pantnagar \\
\hline 3 & C518 & Lyallpur & 53 & PBW503 & PAU, Ludhiana \\
\hline 4 & SG8809 & CCSHAU, Hisar & 54 & 4209 & IIWBR, Karnal \\
\hline 5 & PR45 & IIWBR, Karnal & 55 & PBW511 & PAU, Ludhiana \\
\hline 6 & $2044 \mathrm{~L}$ & IIWBR, Karnal & 56 & UP2565L & GBPUA\&T, Pantnagar \\
\hline 7 & WH1021 & CCSHAU, Hisar & 57 & 4202 & IIWBR, Karnal \\
\hline 8 & WH1135 & CCSHAU, Hisar & 58 & 4208 & IIWBR, Karnal \\
\hline 9 & Sonalika & CIMMYT, Mexico/IARI & 59 & Kanchan & IARI, New Delhi \\
\hline 10 & WH1155 & CCSHAU, Hisar & 60 & PBW621 & PAU, Ludhiana \\
\hline 11 & VL803 & VPKAS, Almora & 61 & PBW373 & PAU, Ludhiana \\
\hline 12 & NIAW1188 & MPKV, Niphad & 62 & 2060 & IIWBR, Karnal \\
\hline 13 & 2002 & IIWBR, Karnal & 63 & 4204 & IIWBR, Karnal \\
\hline 14 & WH787 & CCSHAU, Hisar & 64 & PBW533 & PAU, Ludhiana \\
\hline 15 & WH1158 & CCSHAU, Hisar & 65 & UP2660 & GBPUA\&T, Pantnagar \\
\hline 16 & WH1159 & CCSHAU, Hisar & 66 & HD3064 & IARI, New Delhi \\
\hline 17 & 2045 & IIWBR, Karnal & 67 & 4207 & IIWBR, Karnal \\
\hline 18 & DBW14 & IIWBR, Karnal & 68 & 2084 & IIWBR, Karnal \\
\hline 19 & NW1014 & NDUA\&T, Faizabad & 69 & SGP-6 & CCSHAU, Hisar \\
\hline 20 & NW2069 & NDUA\&T, Faizabad & 70 & 2082 & IIWBR, Karnal \\
\hline 21 & RAJ3765 & SKRAU, Durgapura & 71 & SGP13 & CCSHAU, Hisar \\
\hline 22 & HD2888L & IARI, New Delhi & 72 & HD2830 & IARI, New Delhi \\
\hline 23 & HD1869 & IARI, New Delhi & 73 & SGP-1 & CCSHAU, Hisar \\
\hline 24 & 2042 & IIWBR, Karnal & 74 & PHS829 & IIWBR, Karnal \\
\hline 25 & WH715 & CCSHAU, Hisar & 75 & 2049 & IIWBR, Karnal \\
\hline 26 & WH1124 & CCSHAU, Hisar & 76 & 2047 & IIWBR, Karnal \\
\hline 27 & WH1151 & CCSHAU, Hisar & 77 & Kundan & IARI, New Delhi \\
\hline 28 & HW2036 & IARI, RS, Wellington & 78 & 2099 & IIWBR, Karnal \\
\hline 29 & HD 2285 & IARI, New Delhi & 79 & 2025 & IIWBR, Karnal \\
\hline 30 & WH1165 & CCSHAU, Hisar & 80 & PHR1017 & IIWBR, Karnal \\
\hline 31 & WH1131 & CCSHAU, Hisar & 81 & HD2705 & IARI, New Delhi \\
\hline 32 & WH1164 & CCSHAU, Hisar & 82 & DBW347 & IIWBR, Karnal \\
\hline 33 & WH1133 & CCSHAU, Hisar & 83 & SYN-4 & CIMMYT, Mexico \\
\hline 34 & HUW234 & BHU, Varanasi & 84 & PBW550 & PAU, Ludhiana \\
\hline 35 & HD2687 & IARI, New Delhi & 85 & 2041 & IIWBR, Karnal \\
\hline 36 & RAJ4101 & SKRAU, Durgapura & 86 & PBW527 & PAU, Ludhiana \\
\hline 37 & MB-1 & IIWBR, Karnal & 87 & SYN-14 & CIMMYT, Mexico \\
\hline 38 & WH1156 & CCSHAU, Hisar & 88 & PHR109 & IIWBR, Karnal \\
\hline 39 & 4062 & IIWBR, Karnal & 89 & PHR1006 & IIWBR, Karnal \\
\hline 40 & DBW11 & IIWBR, Karnal & 90 & PBW475 & PAU, Ludhiana \\
\hline 41 & 4066 & IIWBR, Karnal & 91 & HD 2643 & IARI, New Delhi \\
\hline 42 & SGP-7 & CCSHAU, Hisar & 92 & WH1061 & CCSHAU, Hisar \\
\hline 43 & Sonak & CCSHAU, Hisar & 93 & WH789 & CCSHAU, Hisar \\
\hline 44 & PBW175 & PAU, Ludhiana & 94 & PHR1001 & IIWBR, Karnal \\
\hline 45 & PHS210 & IIWBR, Karnal & 95 & SYN-8 & CIMMYT, Mexico \\
\hline 46 & PHS824 & IIWBR, Karnal & 96 & PHR1022 & IIWBR, Karnal \\
\hline 47 & 2072 & IIWBR, Karnal & 97 & UP2338 & GBPUA\&T, Pantnagar \\
\hline 48 & UP2425 & GBPUA\&T, Pantnagar & 98 & PHR1007 & IIWBR, Karnal \\
\hline 49 & 4063 & IIWBR, Karnal & 99 & PBW486 & PAU, Ludhiana \\
\hline 50 & SGP-5 & CCSHAU, Hisar & 100 & WH1140 & CCSHAU, Hisar \\
\hline
\end{tabular}




\subsection{EXPERIMENTAL FIELD}

The experiment were grown in a randomized block design with three replications at Research Area Wheat and Barley Section, Department of Genetics and Plant Breeding CCS Haryana Agricultural University, Hisar in two consecutive years during Rabi 2012-13 and 2013-14. The experiment were conducted in two separate date of sowing first timely sowing dated 15 November and late sowing for heat treatment dated 25 December in both season. Each plot consisted of single row of $3.0 \mathrm{~m}$ length with $22.5 \mathrm{~cm}$ and $10 \mathrm{~cm}$ spacing between row to row and plant to plant, respectively. All the agronomic practices were kept constant with proper irrigation. Weeds were removed manually as and when required.

\subsection{WEATHER INFORMATION}

The precipitation and average temperature for the 2012-13 and 2013-14 cropping season in CCS Haryana Agricultural University, Hisar Campus are presented in Table 2.

Table 2: Temperature and rainfall during wheat crop season of 2012-13 and 2013-14 (Source: AgroMeteorological Observatory Unit CCS HAU, Hisar)

\begin{tabular}{|l|l|l|l|l|l|l|}
\hline \multirow{3}{*}{ Month } & \multicolumn{3}{|l|}{ Temperature $\left({ }^{\circ} \mathrm{C}\right)$} & \multirow{2}{*}{ Rainfall $(\mathrm{mm})$} \\
\cline { 2 - 6 } & $2012-13$ & $2013-14$ & Max & $2012-13$ & $2013-14$ \\
\cline { 2 - 6 } & Min & Max & Min & 21.8 & 5.5 & 0.0 \\
\hline December & 6.0 & 20.8 & 7.0 & 18.0 & 14.4 & 2.0 \\
\hline January & 4.8 & 18.4 & 5.6 & 20.8 & 0.0 & 12.5 \\
\hline February & 8.3 & 21.0 & 7.6 & 26.3 & 0.0 & 47.0 \\
\hline March & 11.9 & 28.0 & 12.2 & 34.1 & 33.3 & 17.1 \\
\hline April & 17.1 & 35.0 & 17.1 & & & \\
\hline
\end{tabular}

\subsection{TRAITS STUDIED}

\subsubsection{PHENOTYPIC PARAMETER}

At maturity five plants from central row were selected at random from each plot in each replication for recording data on grain yield per plant $(\mathrm{gm})$ and biological yield (gm) recorded after physiological maturity. Thousand grain weights $(\mathrm{gm})$, number of grains per spike, spike length $(\mathrm{cm})$, number of spikelets per spike were taken after post harvest. Plant height $(\mathrm{cm})$ and number of productive tillers per plant were taken at physiological maturity. Harvest index was calculated by divided the grain yield with biological yield above ground. Flag leaf area $\left(\mathrm{cm}^{2}\right)$ was calculated at the time of flowering. Days to heading recorded at the time of anthesis and days to maturity were recorded when color of plant turns green to yellowish.

\subsection{STATISTICAL ANALYSIS}

The mean data were subjected to analysis of variance to test the level of significance among the genotypes for various characters. Genotypic and phenotypic variances, genotypic and phenotypic coefficient of variability, broad sense heritability and correlation coefficients were computed according to the method suggested by Singh \& Chaudhary (1985).

\subsection{PHENOTYPIC VARIATION}

\section{Results And Discussion}

The results from analyses of variance over two years in timely sown and late sown conditions for the various traits are presented in Table 3. In this experiment, grain yield and yield related traits of all genotypes were differed significantly $(*, * *$ at $5 \%$ and $1 \%$ probability level, respectively), except harvest index in late sown condition. This indicated the prevalence of enough genetic variability in the materials under study for selection and improvement.

Table 3: Mean sum of squares for various traits under timely sown and late sown conditions

\begin{tabular}{|c|c|c|c|c|c|c|c|c|c|c|c|}
\hline $\begin{array}{l}\text { Source } \\
\text { of } \\
\text { variation }\end{array}$ & $\begin{array}{l}\text { Degree of } \\
\text { freedom }\end{array}$ & $\begin{array}{l}\text { Envir- } \\
\text { onment }\end{array}$ & $\begin{array}{l}\text { Yield/ } \\
\text { Plant (g) }\end{array}$ & $\begin{array}{l}\text { No. of } \\
\text { productive } \\
\text { tillers/plant }\end{array}$ & $\begin{array}{l}1000 \\
\text { Grain wt.(g) }\end{array}$ & $\begin{array}{l}\text { No. of } \\
\text { grains } \\
\text { /spike }\end{array}$ & $\begin{array}{l}\text { Spike } \\
\text { length } \\
(\mathrm{cm}) \\
\end{array}$ & $\begin{array}{l}\text { No. of } \\
\text { spikelets } \\
\text { /spike }\end{array}$ & $\begin{array}{l}\text { Plant } \\
\text { height } \\
(\mathrm{cm})\end{array}$ & $\begin{array}{l}\text { Biological } \\
\text { yield } \\
\text { (g) }\end{array}$ & $\begin{array}{l}\text { Harvest } \\
\text { index } \\
(\%) \\
\end{array}$ \\
\hline Replication & 2 & $\begin{array}{l}\text { TS } \\
\text { LS }\end{array}$ & $\begin{array}{l}3.94 \\
0.173\end{array}$ & $\begin{array}{l}2.45 \\
0.944\end{array}$ & $\begin{array}{l}2.26 \\
1.509\end{array}$ & $\begin{array}{l}1.64 \\
53.7\end{array}$ & $\begin{array}{l}1.81 \\
1.609\end{array}$ & $\begin{array}{l}14.80 \\
2.58\end{array}$ & $\begin{array}{l}21.15 \\
158.57\end{array}$ & $\begin{array}{l}49.38 \\
3.65\end{array}$ & $\begin{array}{l}4.35 \\
5.38\end{array}$ \\
\hline Genotypes & 99 & $\begin{array}{l}\text { TS } \\
\text { LS }\end{array}$ & $\begin{array}{l}722 * * \\
579 * *\end{array}$ & $\begin{array}{l}682 * * \\
329 * *\end{array}$ & $\begin{array}{l}4,626^{* *} \\
3,684^{* * *}\end{array}$ & $\begin{array}{l}8625 * * \\
12214 * *\end{array}$ & $\begin{array}{l}910 \text { *** } \\
444^{* * *}\end{array}$ & $\begin{array}{l}2,145 * * \\
1,479 * *\end{array}$ & $\begin{array}{l}25,669 * * \\
15,834 * *\end{array}$ & $\begin{array}{l}6,346^{* *} \\
4,285^{* *}\end{array}$ & $\begin{array}{l}2,059 * * \\
824\end{array}$ \\
\hline Error & 198 & $\begin{array}{l}\text { TS } \\
\text { LS }\end{array}$ & $\begin{array}{l}193 \\
119\end{array}$ & $\begin{array}{l}139 \\
98\end{array}$ & $\begin{array}{l}101 \\
129\end{array}$ & $\begin{array}{l}2184 \\
2554\end{array}$ & $\begin{array}{l}165 \\
136\end{array}$ & $\begin{array}{l}590 \\
358\end{array}$ & $\begin{array}{l}1,922 \\
815\end{array}$ & $\begin{array}{l}1,567 \\
1,044\end{array}$ & $\begin{array}{l}617 \\
466\end{array}$ \\
\hline C.D. (5\%) & & $\begin{array}{l}\text { TS } \\
\text { LS }\end{array}$ & $\begin{array}{l}1.59 \\
1.25\end{array}$ & $\begin{array}{l}1.35 \\
1.13\end{array}$ & $\begin{array}{l}1.15 \\
1.30\end{array}$ & $\begin{array}{l}5.35 \\
5.78\end{array}$ & $\begin{array}{l}1.47 \\
1.34\end{array}$ & $\begin{array}{l}2.78 \\
2.16\end{array}$ & $\begin{array}{l}.02 \\
3.27\end{array}$ & $\begin{array}{l}4.53 \\
3.70\end{array}$ & $\begin{array}{l}2.84 \\
2.47\end{array}$ \\
\hline Mean & & $\begin{array}{l}\text { TS } \\
\text { LS }\end{array}$ & $\begin{array}{l}11.79 \\
8.11\end{array}$ & $\begin{array}{l}8.02 \\
6.30\end{array}$ & $\begin{array}{l}43.22 \\
35.26\end{array}$ & $\begin{array}{l}58.45 \\
48.00\end{array}$ & $\begin{array}{l}11.47 \\
9.99\end{array}$ & $\begin{array}{l}20.38 \\
17.32\end{array}$ & $\begin{array}{l}98.86 \\
79.07\end{array}$ & $\begin{array}{l}31.50 \\
23.13\end{array}$ & $\begin{array}{l}37.61 \\
35.09\end{array}$ \\
\hline
\end{tabular}




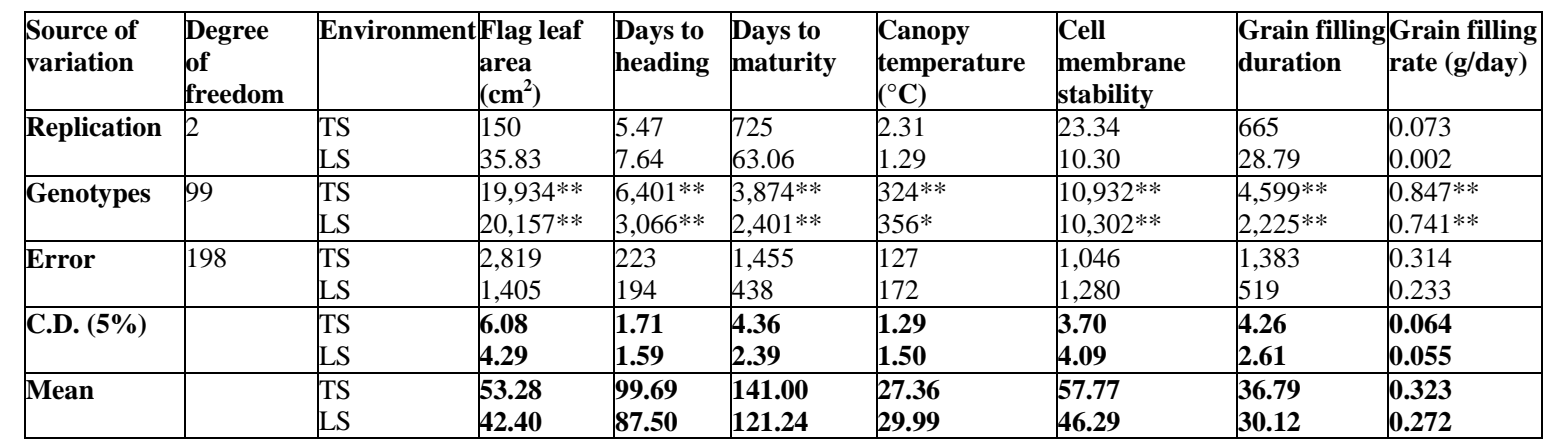

*, **; Significant at 5\% and 1\% level of probability, respectively; TS; Timely sown, LS; Late sown

\subsection{ESTIMATES OF GENETIC VARIABILITY}

Overall genetic and phenotypic variability depends on heritable and non-heritable components. While coefficients of variation measure the magnitude of variability present in a population, estimates of heritability and genetic advances are important preliminary steps in any breeding programs they provide information about effective selection. Genotypic coefficient of variability (GCV), phenotypic coefficient of variability (PCV), broad sense heritability, and genetic advance expressed as percentage of mean for thirteen traits under timely sown and late sown conditions are presented in Table 4.

Table 4: Mean, range, co-efficient of variation (phenotypic and genotypic), heritability (broad sense), and genetic advance (as \% of mean) for various traits under timely and late sown conditions

\begin{tabular}{|c|c|c|c|c|c|c|c|c|}
\hline \multirow[t]{2}{*}{$\begin{array}{l}\text { Sr. } \\
\text { No. }\end{array}$} & \multirow[t]{2}{*}{ Characters } & & \multirow[t]{2}{*}{ Mean \pm SE } & \multirow[t]{2}{*}{ Range } & \multicolumn{2}{|c|}{$\begin{array}{ll}\text { Co-efficient } & \text { of } \\
\text { variations }(\%) & \end{array}$} & \multirow{2}{*}{$\begin{array}{l}\text { Heritability } \\
\text { (broad } \\
\text { sense) }\end{array}$} & \multirow{2}{*}{$\begin{array}{l}\text { Genetic } \\
\text { advance } \\
\text { as \% of } \\
\text { mean }\end{array}$} \\
\hline & & & & & PCV & GCV & & \\
\hline 1 & Yield /plant (g) & $\begin{array}{l}\text { TS } \\
\text { LS }\end{array}$ & $\begin{array}{l}11.79 \pm 0.57 \\
8.11 \pm 0.448\end{array}$ & $\begin{array}{l}7.35-14.61 \\
5.70-11.36\end{array}$ & $\begin{array}{l}14.89 \\
18.90\end{array}$ & $\begin{array}{l}12.30 \\
16.30\end{array}$ & $\begin{array}{l}68.33 \\
74.40\end{array}$ & $\begin{array}{l}20.96 \\
28.96\end{array}$ \\
\hline 2 & $\begin{array}{l}\text { No. of productive } \\
\text { tillers/plant }\end{array}$ & $\begin{array}{l}\text { TS } \\
\text { LS }\end{array}$ & $\begin{array}{l}8.02 \pm 0.485 \\
6.30 \pm 0.407\end{array}$ & $\begin{array}{l}5.33-12.00 \\
4.83-9.33\end{array}$ & $\begin{array}{l}20.74 \\
19.03\end{array}$ & $\begin{array}{l}17.90 \\
15.40\end{array}$ & $\begin{array}{l}74.54 \\
65.52\end{array}$ & $\begin{array}{l}31.84 \\
25.69\end{array}$ \\
\hline 3 & 1000 Grain wt. (g) & $\begin{array}{l}\text { TS } \\
\text { LS } \\
\end{array}$ & $\begin{array}{l}43.22 \pm 0.414 \\
35.26 \pm 0.466\end{array}$ & $\begin{array}{l}31.33-51.76 \\
25.46-45.00 \\
\end{array}$ & $\begin{array}{l}9.23 \\
10.16\end{array}$ & $\begin{array}{l}9.08 \\
9.90\end{array}$ & $\begin{array}{l}96.77 \\
94.92\end{array}$ & $\begin{array}{l}18.40 \\
19.86 \\
\end{array}$ \\
\hline 4 & No. of grains/spike & $\begin{array}{l}\text { TS } \\
\text { LS }\end{array}$ & $\begin{array}{l}58.80 \pm 1.91 \\
48.00 \pm 2.07\end{array}$ & $\begin{array}{l}44.83-68.66 \\
35.33-62.66 \\
\end{array}$ & $\begin{array}{l}10.32 \\
14.68\end{array}$ & $\begin{array}{l}8.61 \\
12.64\end{array}$ & $\begin{array}{l}69.68 \\
74.05\end{array}$ & $\begin{array}{l}14.81 \\
22.41\end{array}$ \\
\hline 5 & Spike length $(\mathrm{cm})$ & $\begin{array}{l}\text { TS } \\
\text { LS }\end{array}$ & $\begin{array}{l}11.47 \pm 0.528 \\
9.99 \pm 0.48\end{array}$ & $\begin{array}{l}8.41-20.35 \\
7.78-15.00\end{array}$ & $\begin{array}{l}16.60 \\
14.01 \\
\end{array}$ & $\begin{array}{l}14.55 \\
11.26\end{array}$ & $\begin{array}{l}76.88 \\
64.67\end{array}$ & $\begin{array}{l}26.28 \\
18.66\end{array}$ \\
\hline 6 & No. of spikelets/spike & $\begin{array}{l}\text { TS } \\
\text { LS } \\
\end{array}$ & $\begin{array}{l}20.38 \pm 0.997 \\
17.32 \pm 0.776 \\
\end{array}$ & $\begin{array}{l}14.66-29.66 \\
11.50-24.33 \\
\end{array}$ & $\begin{array}{l}14.89 \\
14.36 \\
\end{array}$ & $\begin{array}{l}12.24 \\
12.08\end{array}$ & $\begin{array}{l}67.61 \\
70.76\end{array}$ & $\begin{array}{l}20.73 \\
20.93\end{array}$ \\
\hline 7 & Plant height (cm) & $\begin{array}{l}\text { TS } \\
\text { LS }\end{array}$ & $\begin{array}{l}98.86 \pm 1.79 \\
79.40 \pm 1.17\end{array}$ & $\begin{array}{l}84.39-130.44 \\
68.64-99.16\end{array}$ & $\begin{array}{l}9.75 \\
9.47\end{array}$ & $\begin{array}{l}9.22 \\
9.11\end{array}$ & $\begin{array}{l}89.54 \\
92.65\end{array}$ & $\begin{array}{l}17.98 \\
18.07\end{array}$ \\
\hline 8 & Biological yield (g) & $\begin{array}{l}\text { TS } \\
\text { LS }\end{array}$ & $\begin{array}{l}31.50 \pm 1.62 \\
23.13 \pm 1.32\end{array}$ & $\begin{array}{l}21.67-41.83 \\
16.25-33.33\end{array}$ & $\begin{array}{l}16.39 \\
18.32\end{array}$ & $\begin{array}{l}13.73 \\
15.38\end{array}$ & $\begin{array}{l}70.28 \\
70.60\end{array}$ & $\begin{array}{l}23.72 \\
26.63\end{array}$ \\
\hline 9 & Harvest index (\%) & $\begin{array}{l}\text { TS } \\
\text { LS }\end{array}$ & $\begin{array}{l}37.61 \pm 1.02 \\
35.09 \pm 0.88\end{array}$ & $\begin{array}{l}32.42-45.42 \\
31.39-39.62\end{array}$ & $\begin{array}{l}7.98 \\
5.94\end{array}$ & $\begin{array}{l}6.45 \\
4.02\end{array}$ & $\begin{array}{l}65.42 \\
45.78\end{array}$ & $\begin{array}{l}10.75 \\
5.60\end{array}$ \\
\hline 10 & Flag leaf area $\left(\mathrm{cm}^{2}\right)$ & $\begin{array}{l}\text { TS } \\
\text { LS }\end{array}$ & $\begin{array}{l}53.28 \pm 2.18 \\
42.40 \pm 1.53\end{array}$ & $\begin{array}{l}35.33-70.00 \\
26.12-64.00\end{array}$ & $\begin{array}{l}16.43 \\
20.09\end{array}$ & $\begin{array}{l}14.82 \\
19.09\end{array}$ & $\begin{array}{l}81.41 \\
90.22\end{array}$ & $\begin{array}{l}27.55 \\
37.34\end{array}$ \\
\hline 11 & Days to heading & $\begin{array}{l}\text { TS } \\
\text { LS }\end{array}$ & $\begin{array}{l}99.69 \pm 0.613 \\
87.50 \pm 0.572\end{array}$ & $\begin{array}{l}88.83-110.66 \\
79.00-99.00\end{array}$ & $\begin{array}{l}4.74 \\
3.79\end{array}$ & $\begin{array}{l}4.61 \\
3.61\end{array}$ & $\begin{array}{l}94.93 \\
91.04\end{array}$ & $\begin{array}{l}9.26 \\
7.10\end{array}$ \\
\hline 12 & Days to maturity & $\begin{array}{l}\text { TS } \\
\text { LS }\end{array}$ & $\begin{array}{l}141.00 \pm 1.56 \\
121.24 \pm 0.859\end{array}$ & $\begin{array}{l}135.00 \\
152.63 \\
116.00-133.50\end{array}$ & $\begin{array}{l}3.00 \\
2.55\end{array}$ & $\begin{array}{l}2.31 \\
2.24\end{array}$ & $\begin{array}{l}59.04 \\
76.83\end{array}$ & $\begin{array}{l}3.65 \\
4.03\end{array}$ \\
\hline 13 & $\begin{array}{l}\text { Canopy temperature } \\
\left({ }^{\circ} \mathrm{C}\right)\end{array}$ & $\begin{array}{l}\text { TS } \\
\text { LS }\end{array}$ & $\begin{array}{l}27.36 \pm 0.463 \\
29.99 \pm 0.539\end{array}$ & $\begin{array}{l}25.23-30.50 \\
26.73-32.50\end{array}$ & $\begin{array}{l}4.51 \\
4.45\end{array}$ & $\begin{array}{l}3.42 \\
3.18\end{array}$ & $\begin{array}{l}57.62 \\
51.12\end{array}$ & $\begin{array}{l}5.35 \\
4.68\end{array}$ \\
\hline 14 & Cell membrane stability & $\begin{array}{l}\text { TS } \\
\text { LS }\end{array}$ & $\begin{array}{l}57.77 \pm 1.32 \\
46.29 \pm 1.46\end{array}$ & $\begin{array}{l}42.66-71.58 \\
33.66-64.60\end{array}$ & $\begin{array}{l}10.99 \\
13.49\end{array}$ & $\begin{array}{l}10.25 \\
12.32\end{array}$ & $\begin{array}{l}86.89 \\
83.41\end{array}$ & $\begin{array}{l}19.67 \\
23.18\end{array}$ \\
\hline 15 & Grain fill duration & $\begin{array}{l}\text { TS } \\
\text { LS }\end{array}$ & $\begin{array}{l}36.79 \pm 1.52 \\
30.12 \pm 0.935\end{array}$ & $\begin{array}{l}27.85-42.50 \\
24.50-38.60\end{array}$ & $\begin{array}{l}12.23 \\
10.09\end{array}$ & $\begin{array}{l}9.88 \\
8.54\end{array}$ & $\begin{array}{l}65.31 \\
71.61\end{array}$ & $\begin{array}{l}16.45 \\
14.88\end{array}$ \\
\hline 16 & Grain fill rate (g/day) & $\begin{array}{l}\text { TS } \\
\text { LS }\end{array}$ & $\begin{array}{l}0.323 \pm 0.023 \\
0.272 \pm 0.02\end{array}$ & $\begin{array}{l}0.207-0.457 \\
0.167-0.413\end{array}$ & $\begin{array}{l}19.15 \\
21.06\end{array}$ & $\begin{array}{l}14.76 \\
16.87\end{array}$ & $\begin{array}{l}59.43 \\
64.16\end{array}$ & $\begin{array}{l}23.45 \\
27.84\end{array}$ \\
\hline
\end{tabular}

\subsection{GENOTYPIC AND PHENOTYPIC COEFFICIENTS OF VARIATION}

The results revealed considerable phenotypic and genotypic variances among the genotypes for the traits under consideration. The estimates of GCV were high in timely sown and late sown conditions for number of productive tillers (17.90 and 15.40, respectively), flag leaf area (14.82 and 19.09, respectively), grain filling rate (14.76 and 16.87, respectively), yield per plant (12.30 and 16.30, respectively), biological yield (13.73 and 
15.38, respectively), number of spikelet per spike and spike length (14.55 and 11.26, respectively). The PCV values were higher than GCV values for all the traits which reveal the influence of environment on the expression of traits.

\subsection{HERITABILITY IN BROAD SENSE}

The genotypic coefficient of variation along with estimates of heritability in broad sense provide bonafide estimates of the amount of genetic advance to be expected through phenotypic selection (Burton, 1952). The results of the present study indicated that- The estimates of heritability in broad sense were high in timely sown and late sown conditions for 1000 grain weight (96.77 and 94.92 , respectively), days to heading (94.93 and 91.04, respectively), plant height (89.59 and 92.65, respectively), flag leaf area (81.41 and 90.22, respectively), cell membrane stability ( 86.89 and 83.41 , respectively). Moderate heritability were estimate in timely sown and late sown conditions for number of productive tillers (74.54 and 65.52, respectively), yield per plant (68.33 and 74.40, respectively), spike length (76.88 and 64.67, respectively) and number of spikelet per spike (67.61 and 70.76, respectively). High heritability were also calculates and reported by Riaz-Ud-Din, et al., 2010; Sachan and Singh, 2003 ; Adewale et al., 2010; Rahim et al., 2010, for grain yield, number of spikelets per spike, number of seeds per spike, plant height, 100 -seed weight and number of tillers per plant.

\subsection{GENETIC ADVANCE AS PERCENT OF MEAN}

High heritability along with high genetic advance is an important factor for predicting the resultant effect for selection the best individuals. Values are expressed as percentage of the mean for each trait so that comparison could be made among various traits, which had different units of measurement. The estimates of genetic advance as percent of means were high in timely sown and late sown conditions for number of productive tillers ( 31.84 and 25.69 , respectively), flag leaf area ( 27.55 and 34.34 , respectively), grain filling rate (23.45 and 27.84, respectively), biological yield (23.72 and 26.63, respectively), yield per plant (20.96 and 28.96 , respectively), number of spikelet per spike (20.73 and 20.93, respectively) and cell membrane stability (19.67 and 23.18, respectively). From the above discussion, in timely sown and late sown conditions yield per plant, number of productive tillers, spike length, number of spikelet per spike, flag leaf area, cell membrane stability, grain filling rate, biological yield and 1000 grain weight showed ample genetic variance, high to moderate heritability and high to moderate genetic gain. Therefore selection can be based on these traits in both environments.

\subsection{GENOTYPIC CORRELATION AMONG CHARACTERS}

The genotypic correlations for various morpho-physiological traits are presented in Table 5. An understanding of inter-character correlation is essential to successful selection of useful genotypes from the whole population but intensive selection for any characteristic might result in losses in others (Lebsock and Amaya, 1969).

Table 5: Genotypic and phenotypic (bold) correlations for various traits under timely sown and late sown conditions

\begin{tabular}{|c|c|c|c|c|c|c|c|c|c|c|c|c|c|c|c|c|}
\hline & 1 & 2 & 3 & 4 & 5 & 6 & & & 9 & 10 & 11 & 12 & 13 & 14 & 15 & 16 \\
\hline & $\begin{array}{l}\text { TS } \\
\text { LS }\end{array}$ & $\begin{array}{l}0.523 * * \\
0.484 \text { ** }\end{array}$ & $=\left[\begin{array}{l}0.427 \\
0.477 * *\end{array}\right.$ & $=\begin{array}{l}0.419^{\text {** }} \\
0.421^{* \star}\end{array}$ & $\begin{array}{l}0.288^{* *} \\
0.264^{* *}\end{array}$ & $\begin{array}{l}0.192 * * \\
0.020\end{array}$ & $\begin{array}{l}-0.026 \\
0.067\end{array}$ & $\begin{array}{l}0.876^{* *} \\
0.951^{* *}\end{array}$ & $\begin{array}{l}0.097 \\
0.272 \text { ** }\end{array}$ & $=\mid \begin{array}{l}0.439 * * \\
0.392 * *\end{array}$ & $=\begin{array}{l}-0.204^{* * \star} \\
-0.029\end{array}$ & $\begin{array}{l}-0.133 * \\
-0.005\end{array}$ & $\begin{array}{l}-0.298^{*} \\
-0.001\end{array}$ & ${ }^{*} 0.451^{* \star}$ & \begin{tabular}{l|l}
$* 0.068$ \\
\end{tabular} & $0.744^{* *}$ \\
\hline & \begin{tabular}{l|l} 
TS & $0.537 * *$ \\
LSS $0.487 * *$
\end{tabular} & 1 & $\begin{array}{l}0.239 * * \\
0.230^{* *}\end{array}$ & $=0.261^{* *}$ & $=0.146 *$ & $\begin{array}{l}0.091 \\
0.039\end{array}$ & $\begin{array}{l}-0.071 \\
0.039\end{array}$ & $\begin{array}{l}0.487^{* *} \\
0.509 * *\end{array}$ & $\begin{array}{l}-0.015 \\
-0.042 \\
\end{array}$ & $\begin{array}{l}0.250^{* *} \\
0.364^{* *}\end{array}$ & & & & & & \\
\hline & \begin{tabular}{l|l} 
TS & $0.439 * *$ \\
LS & $0.492 * *$
\end{tabular} & $\begin{array}{l}0.238^{* * *} \\
0.239 * *\end{array}$ & & & $=\begin{array}{l}0.014 \\
0.159 * *\end{array}$ & & & & & & & & & & & \\
\hline & \begin{tabular}{l|l} 
TS & $0.455^{* *} *$ \\
LS & $0.368 * *$ \\
\end{tabular} & $0.314^{* *}$ & $\begin{array}{l}0.088 \\
0.201 * *\end{array}$ & & & & & & & & & & & & & \\
\hline & \begin{tabular}{l|l} 
TS & $0.141^{*}$ \\
LSS 0.092
\end{tabular} & $\begin{array}{c}0.042 \\
-0.083 \\
\end{array}$ & $\begin{array}{l}-0.045 \\
0.112\end{array}$ & & & & & & & & & & & & & \\
\hline & $\begin{array}{l}\text { TS }-0.013 \\
\text { LS }-0.151^{*}\end{array}$ & $\begin{array}{l}-0.035 \\
-0.139 *\end{array}$ & & & & & & & & & & & & & & \\
\hline & \begin{tabular}{|l|l|} 
TS & -0.039 \\
LS & 0.074 \\
\end{tabular} & $\begin{array}{l}-0.095 \\
0.036 \\
\end{array}$ & & & & & & & & & & & & & & \\
\hline & \begin{tabular}{l|l} 
TS & $0.886^{* * *}$ \\
LS & $0.967 * *$ \\
\end{tabular} & $\begin{array}{l}0.503^{* * *} \\
0.512^{* *}\end{array}$ & & & & & & ] & & & & & & & & \\
\hline & \begin{tabular}{l|l} 
TS & 0.060 \\
LS & $0.372^{* * *}$
\end{tabular} & $\begin{array}{l}-0.033 \\
-0.004 \\
\end{array}$ & & $\begin{array}{l}0.0 \\
0.0 \\
\end{array}$ & & & $\begin{array}{l}-0.0 \\
-0.1 \\
\end{array}$ & & & & & & & & & \\
\hline & $\begin{array}{l}0.511 * * \\
\text { LS } 0.343 * *\end{array}$ & $\begin{array}{l}0.276^{* * *} \\
0.347^{* * *}\end{array}$ & & & & & & & & & & & & & & \\
\hline & $\begin{array}{l}\text { TSS }-0.344^{* *} \\
\text { LS }-0.108\end{array}$ & $\begin{array}{l}-0.176^{* x} \\
-0.165^{* x}\end{array}$ & & & & & & & $\begin{array}{l}0.032 \\
-0.151\end{array}$ & & $* 1$ & & & & & \\
\hline & $\begin{array}{l}2 \mathrm{TS}-0.206^{* *} \\
\mathrm{LS}-0.034\end{array}$ & & & & & & $\mid \begin{array}{l}0.515^{*} \\
0.296^{*}\end{array}$ & & $\mid \begin{array}{l}0.220^{* * *} \\
0.018\end{array}$ & & & & & & & \\
\hline & $\begin{array}{l}\text { TS }-0.177^{* *} \\
\text { LS }-0.363^{* *}\end{array}$ & & & & & & & & & & & & & & & \\
\hline & $\begin{array}{l}\text { TS } 0.407^{* * *} \\
\text { LS } 0.628^{* *}\end{array}$ & $\begin{array}{l}0.400^{* * *} \\
0.449^{* *}\end{array}$ & $\begin{array}{l}0.415^{* *} \\
0.478^{* * *}\end{array}$ & & & & $\begin{array}{l}-0.129^{\prime} \\
0.031\end{array}$ & & & & & $\begin{array}{l}-0.116^{*} \\
-0.009\end{array}$ & & & & \\
\hline & LS 0. & & & & & & & & & & & & & & & \\
\hline & $\begin{array}{l}\text { TS } 0.713^{* *} \\
\text { LS } 0.883^{* *}\end{array}$ & $0.371^{* *}$ & $0.367^{* * *}$ & & & & -0.081 & & 0.011 & & & & & & & 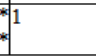 \\
\hline
\end{tabular}




\begin{tabular}{|l|l|l|l|l|l|}
\hline 1 & Yield/plant & 7 & Plant height & 13 & Canopy temperature \\
\hline 2 & $\begin{array}{l}\text { Number of productive } \\
\text { tillers/plant }\end{array}$ & 8 & Biological yield & 14 & Cell membrane stability \\
\hline 3 & 1000 grain weight & 9 & Harvest index & 15 & Grain filling duration \\
\hline 4 & No. of grains/spike & 10 & Flag leaf area & 16 & Grain filling rate \\
\hline 5 & Spike length & 11 & Days to heading & & \\
\hline 6 & No. of spikelets/spike & 12 & Days to maturity & & \\
\hline
\end{tabular}

Bread wheat number of productive tiller $(0.537 * * \& 0.487 * *), 1000$ grain weight $(0.439 * * \& 0.492 * *)$, number of grains per spike $\left(0.455^{* *} \& 0.368^{* *}\right)$, biological yield $\left(0886^{* *} \& 0.967 * *\right)$, flag leaf area $\left(0.511^{* *}\right.$ $\& 0.343 * *)$, cell membrane stability $(0.407 * * \& 0.628 * *)$, grain filling duration $\left(0.207 * * \& 0.149^{* *}\right)$ and grain filling rate $\left(0.713^{* *} \& 0.883^{* *}\right)$ gave the positive associations with grain yield in both the environments, respectively viz., timely sown and late sown, while harvest index $\left(0.372^{* *}\right)$ showed positive correlation only in late sown. Grain yield had negative correlation with days to heading $(-0.344 * *)$ in timely sown condition, indicating that selecting early heading genotypes with long grain filling period. Grain yield had negative correlation with canopy temperature $(-0.177 * * \&-0.363 * *)$ in timely sown and late sown conditions, respectively, indicating that cell functioning viz., transpiration and photosynthesis is proper when canopy temperature is low during the grain filling period. Number of productive tiller had positive correlation with 1000 grain weight $\left(0.238^{* *} \& 0.239 * *\right)$, biological yield $(0.503 * * \& 0.512 * *)$, flag leaf area $(0.276 * * \& 0.347 * *)$, cell membrane stability $\left(0.400^{* *} \& 0.449^{* *}\right)$ and grain filling duration $\left(0.371^{* *} \& 0.443^{* *}\right)$ in both environments, respectively and had negative correlation with canopy temperature $\left(-0.126^{*}\right)$ in late sown condition. The results of correlation coefficients revealed that high grain yield under timely sown condition is due to significant correlations of above physiological and yield attributing traits for grain yield. In both environments bread wheat grain yield were significantly associated with yield attributing traits and physiological traits. Therefore, selection of these traits could be useful in wheat breeding program designed for heat stress condition. Bhutto et al. (2016) reported correlations of plant height which has significantly positively associated with spikelet's per spike, tillers per plant and grains per spike. In bread wheat Bahar et al. (2011) were found significant negative correlations between canopy temperature (CT) and grain yield (GY). Cell membrane stability showed positive correlation with bread wheat grain yield Dhanda and Munjal (2012) concluded lesser leakage of solutes from cellular membrane $\left(r=0.39^{*}\right)$ help in better grain filling under heat stress condition, similar correlation were calculated in the present investigation.

\section{Conclusion}

The present study revealed that the mean sum of squares due to genotypes was recorded significant for all the traits studied except harvest index in late sown condition. This indicated the prevalence of enough genetic variability in the genotypes for selection and improvement. Association study resulted that grain yield per plant had strong and positive genotypic correlation with number of productive tiller per plant, 1000 grain weight, number of grain per spike, biological yield, flag leaf area and cell membrane stability in both environments viz., timely sown and late sown. These traits were the key contributors to yield per plant suggesting the need of more emphasis on these components for increasing the grain yield in wheat while grain yield had negative correlation with days to heading in timely sown condition, indicating that selecting early heading genotypes with long grain filling period. The study of associations among various traits is useful to breeders in selecting genotypes possessing groups of desired traits. In timely sown and late sown conditions yield per plant, number of productive tillers per plant, spike length, number of spikelet per spike, flag leaf area, cell membrane stability, grain filling rate, biological yield and 1000 grain weight showed ample genetic variance, recorded high to moderate heritability and high to moderate genetic gain. Therefore, selection can be based on these traits in both environments. In this investigation, an attempt was made to generate information on inheritance, relationships of yield and its components and their implication in selection of better genotypes of wheat for the development or improvement of cultivars and germplasm under heat stress conditions.

\section{References}

[1]. A. Ayeneh, M. Van-Ginkel, M.P. Reynolds and K. Ammar. 2002. Comparison of leaf, spike, peduncle and canopy temperature depression in wheat under heat stress. Field Crops Res. 79:173-184.

[2]. A.H. Bhutto, A.A. Rajpar, S.A. Kalhoro, A. Ali, F.A. Kalhoro, M. Ahmed, S. Raza and N.A. Kalhoro. 2016. Correlation and Regression Analysis for Yield Traits in Wheat (Triticum aestivum L.) Genotypes. Natural Science. 8:96-104.

[3]. A.S.M.H.M. Talukder, G.K. McDonald, G.S. Gill. 2014. Effect of short-term heat stress prior to flowering and early grain set on the grain yield of wheat. Field Crops Research. 160:54-63.

[4]. B. Bahar, M. Yildirim, and C. Yucel. 2011. Heat and drought resistance criteria in spring bread wheat (Triticum aestivum L.): Morpho-physiological parameters for heat tolerance. Scientific Research and Essay. 6(10):2212-2220.

[5]. B.D. Adewale, C. Okonji, A.A. Oyekanmi, D.A.C. Akintobi, and C.O. Aremu. 2010. Genotypic variability and stability of some grain yield components of Cowpea. Afr. J. Agric. Res. 5(9):874-880.

[6]. C. Chen, W.A. Payne, R.W. Smiley and M.A. Stoltz. 2003. Yield and water-use efficiency of eight wheat cultivars planted on seven dates in northeastern Oregon. Agro J. 95:836-843. 
[7]. C. Rosenzweig, J. Elliott, D. Deryng, A.C. Ruane, C. Müller, A. Arneth, K.J. Boote, C. Folberth, M. Glotter, N. Khabarov, K. Neumann, F. Piontek, T.A.M. Pugh, E. Schmid, E. Stehfest, H. Yang, and J.W. Jones. 2014. Assessing agricultural risks of climate change in the 21 st century in a global gridded crop model intercomparison. Proceeding of National. Academy Science. 111(9):3268-3273

[8]. C.M. Cossani and M.P. Reynolds. 2012. Physiological traits for improving heat tolerance in wheat. Plant Physio. 160:1710-1718.

[9]. C.P. Baril. 1992. Factor regression for interpreting cultivar-environment interaction in bread-wheat trials. Theo Appl Genet. 83:1022-1026.

[10]. D.B. Lobell, W. Schlenker and J. Roberts. 2011. Climate trends and global crop production since 1980. Science. 333:616-620.

[11]. I.F. Wardlaw, I.A. Dawson and Munibi. 1989. The tolerance of wheat to high temperatures during reproductive growth: II.Grain development. Aust. J.Agric. Res. 40:15-24

[12]. J. Rane, and S. Nagarajan. 2004. High temperature index for field evaluation of heat tolerance in wheat varieties. Agri Sys. 79:243255

[13]. K. Frieler, A. Levermann, J. Elliott, J. Heinke, A. Arneth, M.F.P. Bierkens, P. Ciais, D.B. Clark, D. Deryng, P. Döll, P. Falloon, B. Fekete, C. Folberth, A.D. Friend, C. Gellhorn, S.N. Gosling, I. Haddeland, N. Khabarov, M. Lomas, Y. Masaki, K. Nishina, K. Neumann, T. Oki, R. Pavlick, A.C. Ruane, E. Schmid, C. Schmitz, T. Stacke, E. Stehfest, Q. Tang, D. Wisser, V. Huber, F. Piontek, L. Warszawski, J. Schewe, H. Lotze-Campen and H.J. Schellnhuber. 2015. A framework for the cross-sectoral integration of multimodel impact projections: Land use decisions under climate impacts uncertainties. Earth Systematic Day. 6:447-460.

[14]. K. Soyema, J.U. Ahmed, T. Hossain, M.R. Islam and M.M.U. Din. 2016. Variation of Wheat Cultivars in Their Response to Elevated Temperature on Starch and Dry Matter Accumulation in Grain. International Journal of Agronomy. 6:6.

[15]. L.R. Gibson and G.M. Paulsen. 1999. Yield components of wheat grown under high temperature stress during reproductive growth. Crop Sci. 39:1841-1846.

[16]. M. Hussain, M. Farooq, K. Jabran, H. Rehman and M. Akram. 2014. Exogenous glycine betaine application improves yield under water-limited conditions in hybrid sunflower. Arch Agron Soil Science. 54:557-567.

[17]. M. Irfaq, T. Mohammad, F. Subhan, M. Amin, S. Tariq. 2007. Agronomic evaluation of different bread wheat cultivars for terminal heat stress. J Bot Pak. 39:2415-2425.

[18]. M. Irfaq, T. Muhammad, M. Amin and A. Jabbar. 2005. Performance of yield and other agronomic characters on four wheat cultivars under natural heat stress. Inter J Bot.1:124-127.

[19]. M.A. Rahim, A.A. Mia, F. Mahmud, N. Zeba, and K.S. Afrin. 2010. Genetic variability, character association and genetic divergence in Mungbean (Vigna radiataL. Wilczek). POJ. 3(1):1-6.

[20]. M.S. Sachan and S.P. Singh. 2003. Genetics of yield and its components in durum wheat (Triticum durum Desf.). J. Interacademicia, India. 7(2):140 -143.

[21]. Prerna, A. Kumar and R.S. Sengar. 2013. Evaluation of heat and drought Tolerance of wheat cultivars through physiological, biochemical and molecular approaches. Res. J. Agril. Science. 4:139-145.

[22]. R.K. Singh, and B.D. Chaudhary. 1985. Biometrical methods in quantitative analysis. Kalyani, Publishers. New Delhi.

[23]. S.S. Dhanda, R. Munjal. 2012. Heat tolerance in relation to acquired thermotolerance for membrane lipids in bread wheat. Field Crops Research. 135:30-37.

[24]. U.D. Riaz, G.M. Subhani, N. Ahmad, M. Hussain and U.R. Rehman. 2010. Effect of temperature on development and grain formation in spring wheat. Pak. J. Bot. 42(2):899-906.

[25]. Y. Ali, B.M. Atta, J. Akhter, P. Monneveux and Z. Lateef. 2008. Genetic variability, association and diversity studies in wheat (Triticum aestivum L.) germplasm. Pak. J. Bot. 40(5):2087-2097. 